\title{
Knowledge as Film vs. Knowledge as Photo: Alternative Models in Early Soviet Thought
}

\author{
DANIELA STEILA \\ University of Turin, Italy; email: daniela.steila@unito.it \\ Commentary by EVGENI PAVLOV
}

\begin{abstract}
Keywords: knowledge, reflection, Bogdanov, Lenin, organization, experience
While Lenin considered human knowledge to be similar to a mirror-like reflection of the object, Aleksandr Bogdanov emphasized the creative role of the subject in organizing the world. On the basis of some textual evidence, it is possible to describe the epistemologies of the two most influential Russian Marxists at the beginning of the twentieth century using the two metaphors of photography, on the one hand, and cinema, on the other. In particular, while discussing Einstein's relativity, Bogdanov considers sense organs, memory, and all the apparatus of human knowledge 'as a certain kind of cinematographic device'. Sergei Eisenstein deems that cinema is 'an excellent instrument of perception ... for the sensation of movement'. Although it is difficult to find compelling proof of exchange and influence, this is an actual 'tangential point' between Bogdanov's and Eisenstein's ideas on human knowledge.
\end{abstract}

In intellectual history, influence is a major topic, and also a very difficult one. In order to prove contacts or impacts of ideas, one has to provide evidence of connections, readings, discussions, comments, notes, and the like. This is the intriguing and fascinating detective side of the intellectual historian's work, looking for the 'smoking guns' that would definitely prove relationships, exchanges, influences. In the case of Aleksandr Bogdanov and Sergei Eisenstein, both extremely compelling figures in early Soviet thought, we shall consider that, though belonging to different generations, they shared a common milieu, the Proletkult movement of the 1920s, where Bogdanov was a leading figure, and Eisenstein a young and active member (Tikka 2009; Biggart 2021). Eisenstein, however, did not explicitly refer to Bogdanov in his works; nor did he openly discuss the latter's ideas. Their relationship needs to be examined by a variety of interdisciplinary methods, which only a wide collective effort will probably be able to achieve. My paper aims at contributing to such a picture.

Bogdanov was interested in cinema long before the Revolution, and maintained that cinema could be used to educate the new proletarian class. This is not surprising since Bogdanov had a serious interest in science and technology. In his first utopian novel, Red Star, in 1907, he imagines innovative uses for both photography and cinema. He emphasizes the already existing application of photography in photo-telescopes: on Mars there are telescopes that take such precise and accurate pictures that they can be enlarged in order to show details invisible to the naked eye. Menni, a Martian technician, explains to the author's alter ego, Leonid, that the 'direct-vision magnification' of a certain 
telescope 'is about $600, \ldots$ but when that is insufficient we take a photograph and examine it under a microscope, which raises the power to 60,000 or more' (Bogdanov 1984: 40).

On Mars, photos are also used to capture an audience's attention during presentations. Another Martian character, Enno, gives'a fascinating account' of a distant planet, 'its deep, storm-tossed oceans and towering mountains, its scorching sun and thick white clouds, terrible hurricanes and thunderstorms, grotesque monsters and majestic giant plants. He illustrated his lecture with moving pictures on a screen which took up an entire wall of the auditorium.' Leonid notices that 'Enno's voice was the only sound to be heard in the darkness; the audience was plunged into deep concentration' (Bogdanov 1984: 72-73). A person so deeply interested in the development of a new sort of 'pedagogy' in order to develop proletarian culture, as Bogdanov was throughout his whole life, was obviously thinking of possible pedagogical applications of such new means of representation and communication.

On Mars, cinema turns out to be very powerful. Concerning its technical potential, Bogdanov's imagination extends beyond development of sound cinema, which was already being experimented with on Earth, and envisages 3D movies. Leonid reports in the novel that

the theater in our little town had one feature that held particular fascination for me, namely the fact that no actors performed there at all. The plays were either transmitted from distant large cities by means of audiovisual devices, or - more usually - they were cinematic reproductions of plays performed long ago, sometimes so long ago that the actors themselves were already dead. The Martians have mastered the technique of instantaneous color photography and use it to capture life in motion, much as in our cinema theaters. But not only do they combine the camera with the phonograph, as we are thus far rather unsuccessfully beginning to do on Earth, they also employ the principle of the stereoscope to give the moving pictures natural depth. Two images, the two halves of the stereogram, are projected simultaneously onto the screen, and in front of each seat in the auditorium is fastened a set of binoculars, which combines the two flat pictures into three-dimensional ones. It was eerie to watch people moving, acting, and expressing their thoughts and feelings as vividly and distinctly as in real life and yet know that there was actually nothing there but a plate of frosted glass in front of a phonograph and an electric light operated by a clockwork mechanism. It was a weird, almost mystical phenomenon that filled me with a vague sense of unreality. (Bogdanov 1984: 87-88)

The last sentence of this amazing description of the 3D Martian movie theatre is especially significant. According to Bogdanov, cinema turns out to be the best technical means of'reproducing'reality in such a faithful, precise way that reproduction becomes a sort of reality itself, a sort of 'mystical' experience.

The problem of the relationship between perception and reality was a central topic of discussion among Russian Marxists at the very beginning of the twentieth century, and it became so - again in the 1920s. Within a common materialist framework, which necessarily considers human beings as part of the material world, and sense perception as the first and basic connection between knowing subject and known object, one can describe the two main epistemological models developed within Russian Marxism at the time in terms of the two metaphors of photography, on the one hand, and cinema, on the other.

It is well known that Lenin proposed his own epistemology as the only one consistent with 'orthodox' Marxism, which relied on the whole history of materialism as opposed to idealism. As Friedrich Engels stated in his Ludwig Feuerbach and the End of Classical German Philosophy, in the whole history of thought, philosophers split into two great fields:'Those who asserted the primacy of the mind over nature ... comprised the camp of idealism. The others, who regarded nature as primary, belong to the various schools of materialism' (Engels 1886: 366). As far as epistemology is concerned, materialists explain human knowledge starting from the impressions that the external objects provide on the 
sense organs of the human body. Such fundamental empiricism was considered by Russian 'orthodox' Marxists as their sound standpoint. However, G. V. Plekhanov, the well-known 'father of Russian Marxism', whom Lenin openly declared to be his own 'master' in philosophy (Lenin 1924: 343; 1921 : 94), had developed a peculiar 'theory of hieroglyphics' relying both on the philosophical tradition of French eighteenth-century materialism and on modern physiology (Steila 1991). According to him, our impressions are undeniably subjective and cannot be identified with material movements, which are the objective bases of impressions and excite our sensations. However, there is an exact correspondence between the objective conditions of a certain thing and the sensation we feel when such a thing stimulates our sense organs. Plekhanov concludes that 'our sensations are some kind of hieroglyphics that make us aware of what is happening in reality. Hieroglyphics do not resemble the events they communicate, but they are capable of communicating with absolute accuracy the events themselves and - what is of prime importance - the relations that exist among them' (Plekhanov 1892: 501). So, according to Plekhanov, the 'truth' of our sensations does not consist in their being a 'mirror image' of things but in their providing us with undistorted representations of the real relations among things or events. Lenin, however, deemed this to be the weakest point in Plekhanov's thought. As he wrote,'Plekhanov was guilty of an obvious mistake in his exposition of materialism' (Lenin 1909: 238). Lenin compared Plekhanov's theory of hieroglyphs with Hermann von Helmholtz's views on perception and experience, and endorsed Albrecht Rau's criticism of the latter, in order to criticize Plekhanov. In Lenin's words, 'an image can never wholly compare with the model, but an image is one thing, a symbol, a conventional sign, another. The image inevitably and of necessity implies the objective reality of that which it "images". "Conventional sign", symbol, hieroglyph are concepts that introduce an entirely unnecessary element of agnosticism' (Lenin 1909: 235).

Instead of Plekhanov's unnecessary emphasis on conventional signs, Lenin proposes his own theory of knowledge as 'reflection', which he considers much more consistent with the whole tradition of philosophical materialism. According to his view, the camera is a good example to describe how we know reality. In Materialism and Empirio-criticism, one reads that 'objective reality ... is given to man by his sensations, and ... is copied, photographed and reflected by our sensations, while existing independently of them' (Lenin 1909: 130). Any photographer would object that the camera is by no means a 'neutral' instrument for the reproduction of reality. First of all, owing to its technical characteristics, it provides us with a two-dimensional account of three-dimensional reality. Besides, at the beginning of the century, colour reproduction was far from being precise. Finally, as we know very well, in any picture it is always the author's 'framing' that defines what is actually photographed.

Nevertheless, the camera is often considered, in popular understanding, to be a reliable means of reproducing reality, a sort of reflecting mirror. Of course, the image we see in the mirror is not at all identical with the real object, and the same is true for our perceptions, as it has been well known since ancient times, and testified to by a huge philosophical literature on the topic of'sense-deception'. What the example of the camera as a faithful reproducing device really means is that, in spite of the technical specificities of the camera, and the peculiarities of our sense organs, the object remains the very same object within the photo as within our sensations. The object exists as such independently of our perception or photography, which merely reproduces it.

In Lenin's works, the example of photography as a faithful reproduction of reality is used very rarely. Lenin uses the word 'photography' in Materialism and Empirio-criticism, as quoted above, and once again in 1909, referring to a polemical article he was writing on 'Ideological Decay and Disunity Among Russian Social-Democrats.' This essay is defined as 'an instantaneous photograph of one of the rivulets of that broad torrent of ideological confusion' (Lenin 1933: 109), which gave rise to different ideological movements dividing Russian Social-Democracy. Again, a photograph means a representation of reality, in this case a quite complex reality, corresponding to the object itself. 
This meaning of the word 'photograph'was widespread in Russian scientific literature at the end of the nineteenth century. For instance, the well-known physiologist I. M. Sechenov wrote in 1892 that 'the eye refers to forms and movements, like a photographic record, capable of clearly perceiving not only motionless, but also moving, forms; therefore the similarity between what is sensed and the real is here as tangible as the similarity between a human being's face and his or her photo' (Sechenov 1892: 472).

Sechenov was one of the authorities that Plekhanov relied on while developing his theory of hieroglyphs, but Lenin did not address Sechenov, while criticizing Plekhanov, ${ }^{1}$ since he respected Sechenov as a leading figure of Russian science. ${ }^{2}$ Photography was in general considered a good representative of realistic mirror-like knowledge within materialism, and not only by Lenin. Cinema, on the contrary, is never used by Lenin as a metaphor for knowledge. In his works, one can find only a few passing references to the topic, mainly relating to propaganda documentaries and their possible impact (for instance in 1913 in order to criticize its ideological use by German Catholics or Taylorist capitalists; or after the Revolution to support its ideological use for the benefit of the victorious Revolution) (Lenin 1913a: 594; 1913b: 245; 1930: 112; 1920: 161; 1928: 406; 1925).

Amongst those Marxists who were critical of Lenin's and Plekhanov's'orthodoxy', photos were not considered at all a good example of how knowledge works. One of the first to reject the analogy was Joseph Dietzgen, who became very popular in Russia at the beginning of the twentieth century amongst the so-called Machian Marxists, that is, the opponents of Lenin (Steila 2013: 237-251). Marx himself described Dietzgen as a representative of an 'autodidactic philosophy - pursued by workers themselves'(Marx 1867: 497). Engels acknowledged that this German worker succeeded in understanding dialectics by himself, independently of Hegel (Engels 1886: 383-384). On the other hand, Ernst Mach, in the Preface to the Russian translation of his Analysis of Sensations, wrote that'J. Dietzgen ... has reached conclusions very similar to those presented in this book' (Mach 1908: 4). Similarities between Dietzgen's positions and Machian thought (the ideas of Mach himself, and those of his Russian followers) were often emphasized at the time (Kautsky 1909; lushkevich 1907: 80, 86-88; Valentinov 1908: 161-168; Dauge 1907: VIII), and also later. In 1925, for instance, while discussing Bogdanov's Tektology, I. Vainshtein pointed out some parallels between Bogdanov's theory of organization and Dietzgen's thought (Vainshtein 1925). Dietzgen criticized the epistemology of 'reflection' exactly by maintaining that the camera does not take pictures conforming to reality. He wrote: 'Nothing more insipid has been said of truth and knowledge than ... that truth is the conformity of our knowledge with its object. How can a picture "conform" to its model? Approximately it can ... But to be altogether alike, quite the same as the original, what an abnormal idea!' (Dietzgen 1870-1875: 140).

These topics became again very important during the 1920s. Since, by this time, Bogdanov had become a prominent figure within the Proletkult movement, and since he maintained, as it were, un-orthodox theoretical positions in relation to the basic principles of official Marxism, Lenin's Materialism and Empirio-criticism was republished in a second edition, which became much more influential than the first. When the book came out for the first time in 1909, most readers took it to be mainly a polemical work, as part of the ideological struggle within the Bolshevik fraction at that time (Steila 2013: 328-339). But in 1920 its second edition was put forward as an authoritative statement of Marxist orthodox epistemology. The postface by V. I. Nevskii, Dialectical Materialism and the Philosophy of Dead Reaction, made it clear that Lenin's work represented the orthodox positions within Marxist thought, and that Bogdanov was to be condemned as a dangerous heretic. The main charge was that 'Bogdanov ... obstinately maintains, now as before, that the physical world is "socially organized experience'"' (Nevskii 1920: 331). Furthermore, in his later works (Nevskii mentioned Philosophy of

1 When criticizing Plekhanov's theory of knowledge, Lenin rather considers it to derive from Helmholtz's positions. On the connections among Plekhanov, Sechenov and Helmholtz, see Steila 1991.

2 Lenin asked his mother to send to him in Geneva a copy of Sechenov's recent book Elementy mysli in 1904. See Lenin 1904. 
Living Experience, Proletarian Culture, Outlines of the Science of Organization, Tektology ...) Bogdanov had repeated the same mistakes that he was accused of by Lenin in Materialism and Empirio-criticism. In order to show which kind of mistakes these were, Nevskii mentioned Bogdanov's conception of the 'physical' as depending on collective experience. Bogdanov wrote: 'Physical experience is the experience of someone - of all humanity in its development, to be precise. This is the world of strict, established, worked-out regularity and the world of specific, exact correlations. It is that well-ordered world in which all theorems of geometry, all formulas of mechanics, astronomy, physics, etc. operate. Is it possible to accept this world, this system of experience as being independent of humanity? Is it possible to say that it existed before humans did?' (Bogdanov 2016: 218). He answered: '[l]f it is said that the law of gravity operated before there were human beings, then this is not the same as saying that it is independent of human beings' (Bogdanov 2016: 219). This was the breaking point between orthodox Marxist, on the one hand, and Bogdanov's science of organization, on the other. Nevskii's postface inflamed the discussion over Bogdanov's whole system of thought.

A few years later, in 1923, Bogdanov contributed to an interesting book on Einstein's theory of relativity. This volume includes the translation of an extensive essay by Moritz Schlick, and some articles by Russian Marxist philosophers: one by Bogdanov's close friend Vladimir Bazarov, on space and time in the light of the new theory; Bogdanov's essay on the theory of relativity from the organizational point of view; and a work by Pavel lushkevich on the philosophical meaning of relativity. Bogdanov maintains that Einstein's theory is of great importance for his own general science of organization. From such a standpoint, 'the question of the correlations between a complex (any kind of complexphysical, biological, psychical, social) and its environment' turns out to be a key problem (Bogdanov 1923: 101). ${ }^{3}$ Einstein's theory considers the movement of physical bodies as a specific case of such a general problem. In Bogdanov's words: 'Transfer represents a particular case of interaction of a body with its environment, a special case: the body loses and gains not energy, but the link with its environment, loses a link (spatial contact) with some elements, gains a link with others. Conventional thinking sees there two facts: 1) the environment itself is not moving; 2 ) the body moves. The theory of relativity works on the premise that here there is one fact, not two. It is the correlation of the two sides that changes; depending on the position of the knowing subject, this might be expressed in one way or another' (Bogdanov 1923: 102).

In order to understand movement from the standpoint of the theory of relativity, more than one observer is needed. Classic physics assumes one observer, whereas the new physics requires a sort of collective, social engagement: 'Since a single observer cannot occupy two positions at the same time, even mentally, the question of coordination appears to be essentially a specific organizational-social task: to unify, to connect the knowledge of two observers, one of whom is really or mentally attached to the moving body, the other to its environment, whilst each of them operates with their own instruments of orientation, their own system of space-time coordinates' (Bogdanov 1923: 104-105).

Bogdanov was therefore able to accept Einstein's theory as a confirmation of his own thinking, since Einstein's theory moved towards a sort of 'not-subjective' relativism, thereby developing further Mach's point of view (Bogdanov 1923: 121).

The content of the whole book on relativity focuses on the idea that Einstein's theory should be considered as a confirmation, and perhaps a development and a regeneration, of the old Machism. lushkevich, who examines the philosophical significance of Einstein's theory, writes that the theory of relativity is 'wholly filled with the spirit of those influences, which its author acknowledged, when referring to Hume and Mach as the thinkers who gave him conceptual inspiration for his 
work'. lushkevich concluded that 'the theory of relativity is the rebirth of modern positivism, which receives here new confirmation and support' (lushkevich 1923: 155). ${ }^{4}$

In his discussion of Einstein's relativity, Bogdanov states that'our sense organs, memory, and all the scientific auxiliary means for perceiving and recording facts, can be considered as a certain kind of cinematographic device' (Bogdanov 1923: 107). Let us examine the context in which such a statement appears. Bogdanov is explaining that'the theory of relativity formulates the corrections, through which one can move from the projections and forms of the events of the system $A$ within the system $B$ to the 'reality' of those events in the very system $A$, where they take place, and vice versa' (Bogdanov 1923: 107). This possibility can be explained through the image of 'instantaneous photographs' of one system, taken from the other. But at this point Bogdanov makes the statement quoted above, and emphasizes that it will be more correct and effective to compare our perceptual devices to cinema instead of photography. He explains:

If two such devices, within the systems $A$ and $B$, simultaneously film the other system, each 'film' will be unfaithful, 'distorted' when compared with a film taken within the same system: the representations of bodies will be foreshortened in the line of the movement, the very course of the events is slowed down ('the clock lags behind'), for each in the same way and from their respective vantage points. A person, for instance, in these 'films' has a certain height when standing up, and another when lying down. It is clear that formulas permitting one to move from the coordinates of one system to another should be understood as being formulas of correction for the passage from more or less distorted representations to the internal reality of each system: formulas of substitution (podstanovka) of things and events, to be applied to their perceptible forms. (Bogdanov 1923: 107)5

This passage is particularly interesting. Here, Bogdanov inserts the theory of relativity into his own perspective of knowledge as the 'construction' of reality by collective subjects. The formulas that allow one to move from one system to the other are called 'formulas of substitution' (podstanovka). The term 'substitution' (podstanovka) was used by Bogdanov since Empiriomonism to mean a methodological approach aimed at explaining phenomena and events within life as well as within science (Bogdanov 1995: 53).

According to Bogdanov,

substitution consists in the fact that one object or phenomenon is replaced for the purpose of cognition by another real or mental phenomenon. For instance, certain images, sentiments, moods, that a work of art stimulates in the person who reads it, looks at it, or listens to it, are 'placed' beneath such a work, and the sum of all the colored rays, into which a white sun ray is decomposed through the prism, is placed 'beneath' such a white ray, etc. (Bogdanov 1995: 52)

The main point for Bogdanov is that substitution is not an individual but a collective method of constructing reality: 'The principle of substitution lies in the communication among people, in their mutual understanding' (Bogdanov 1995: 52). Substitution is the method by which a human group in

4 Einstein himself acknowledged certain influence of Mach's ideas on his own positions as a young scientist (see Einstein 1951: 20-21 and Blackmore 1972: 247-285).

5 «Если два таких аппарата, находясь в системах А и B, делают взаимно съемку этих систем, то их «фильмы» будут изменены, «искажены» по сравнению со съемкою из своей системы: изображения тел окажутся укорочены по линии движения, самый ход событий замедлен («отставание часов»), то и другое одинаково с обеих сторон. Человек, напр., на этих “фильмах" имеет один рост, когда он стоит, и другой, - когда лежит. Ясно, что формулы перехода от координат одной системы следует понимать как формулы поправок для перехода от более или менее искаженных изображений к внутренней действительности каждой системы, формулы подстановки вещей и событий под их воспринимаемые образы." 
a certain epoch responds to the practical and theoretical need for a harmonious and unified worldview. Within such a worldview, human beings can understand each other and interact with reality. ${ }^{6}$

Famously, in Bogdanov's view, experience is essentially social. For instance, Bogdanov wrote in Empiriomonism

that the world of experience was crystallised, and continues to be crystallised, out of chaos. Communication among people is the force through which the forms of this crystallisation are determined. Properly speaking, there is no experience outside these forms, because the unorganised mass of experiences is not experience. Thus, experience is social at its very foundation, and experience progresses through the socio-psychological process of its being organised to which the individual-psychological organising process is entirely adapted. (Bogdanov 2019:291)

To understand how substitution works means not just to become aware of a sort of spontaneous process within one's own consciousness but to appreciate the deep social nature of such a process. In one of Bogdanov's unpublished letters to Bazarov, one reads: 'Substitution is a complicated product of social development, and it is particularly wrong to confuse it with the passage from perception to apperception. Substitution is a problem of cognitive methodology, i.e. a problem of the social - not just the psychological - order, and it emerges on the basis of social symbolism.'

From the standpoint of Bogdanov's thought, the theory of relativity could be seen as a new perspective, capable of producing a better form of substitution. Bogdanov considers this to be an instance of the 'unifying tendency' that was at work within natural sciences (Bogdanov 1996: XVI). In the first book of Tektology, he writes about the theory of relativity that 'its formulation and analysis are entirely based upon the relationships between observers accepting these or other events, and upon the conditions of signaling which let them co-ordinate their observations. The notion of the physical environment is evidently expanded here in the organizational sense; it is complemented by elements never before taken into account, namely, enquiring beings and their relationships' (Bogdanov 1996: 100).

Such a view overcomes the classic physics of the 'single observer' and creates new opportunities for epistemology to overcome the subjectivity of a single point of view within one system and to take into account other systems. Communication allows people to develop a wider worldview. It is not fortuitous that the example Bogdanov uses to illustrate how we can employ the formulas of substitution to move from one set of representations to another is a classical epistemological problem. In Bogdanov's words:

[L]et us imagine a person living in a cave; its entrance is blocked by an optical-deforming pane; he can observe and study the external world only through this pane. It is evident that all the measures and relations in this world for that person are distorted in a certain way. In order to predict the positions of moving external objects, that person must use formulas, similar to the formulas of the general theory of relativity, in particular, Gaussian coordinates. But in exactly the same way all measures and relationships of everything that happens within the cave are distorted for an observer on the outside. If both sides succeed in identifying the properties of the medium separating them, by introducing corrections in their observations they will be able to establish a precise picture of the things and the events. (Bogdanov 1923: 107-108) 
In other words, a new, better substitution is achieved.

In one endnote in the first book of Tektology, Bogdanov maintains that'current formulations of the "principle of relativity" elaborated by Einstein and others do not seem to me ... to be definitive from an organizational point of view', since 'they always assume only two observers and the light signaling between them' (Bogdanov 1989: 137). Bogdanov continues:

For example, since direct light signaling would be impossible if observers were moving away from each other faster than the speed of light - a ray of light from one could not reach the other - then it is assumed that the relative speed of bodies is always less than the speed of light; and that the speed of light is the fastest possible speed. However, if we introduce into the system of coordination a third observer as an intermediary between the two, we obtain a different result. (Bogdanov 1989: 137)

Furthermore, if two electrons fly out from a radioactive nucleus at a speed close to the speed of light,

it would seem perfectly clear that they are objectively moving apart from each other ... faster than the speed of light. If one could imagine individual observers located on each of these particles, then they will be able to establish this through the intermediary of the observer placed between them, although observations without an intermediary would give them a different result. (Bogdanov 1989: 137-138)

Bogdanov concludes that 'the application of the organizational point of view leads to a far more simple conception of the relativity principle than the usual one' (Bogdanov 1989: 138).

From the standpoint of the general theory of organization, it is perfectly understandable that human beings can change their frameworks, their pattern of interpretation of reality, since those frameworks have nothing to do with Kant's forms of cognition. Bogdanov emphasizes that, 'truly, there are certain forms of thinking that people use to consolidate their experience; but they are by no means the eternal "constitution of cognitive capacities". They are means for the organization of experience, which are developed and altered with the growth of experience and the alteration of its contents' (Bogdanov 1996: 47).

In Bogdanov's view, the knowing subject is by no means a sort of passive recorder of perceptual data, a 'camera' as in Lenin's epistemology. Instead, one could claim, the human collective is engaged in the production of reality and its organization, one could say in its 'montage'.

We cannot find a'smoking gun'that proves evidentially that the young Eisenstein read Bogdanov's epistemological essays. But, curiously enough, according to Eisenstein as well as Bogdanov, cinema could provide us with an orientation in the four-dimensional space-time continuum, which is implicit in Einstein's theory of relativity. In Eisenstein's essay 'The Filmic Fourth Dimension', we read:

The fourth dimension? Einstein? Or mysticism? Or a joke? It is time to stop being frightened of this new knowledge of a fourth dimension. ... Possessing such an excellent instrument of perception as the cinema - even on its primitive level - for the sensation of movement, we should soon learn a concrete orientation in this four-dimensional space-time continuum, and feel as much at home in it as in our own house-slippers. (Eisenstein 1949: 69-70)

Cinema is 'an excellent instrument of perception ... for the sensation of movement', according to Eisenstein (1949: 70). According to Bogdanov,'our sense organs, memory, and all the scientific auxiliary means to perceiving and recording facts, can be considered as a certain kind of cinematographic device' (Bogdanov 1923: 107). This may not provide evidence for a direct or mutually acknowledged 
exchange of ideas between Eisenstein and Bogdanov, but it can certainly be regarded as a tangential point of encounter.

\section{Commentary by Evgeni Pavlov}

Daniela Steila's contribution revisits a well-known conflict between Lenin and Bogdanov, but provides an interesting and fresh interpretation of that disagreement in terms of alternative models or metaphors for perception: a (static) photograph and a (moving) cinematic presentation. Both photography and cinematography were quite novel at the time when Russian Marxists were debating the nature of reality and our ability to cognize it, the former having reached the general public in the 1880s with the rise of Kodak and the latter in the 1890s, with the Lumière brothers. The use of a metaphor to understand the nature of perception, and, ultimately, the nature of reality, originally founded itself on a known, if dubious, dichotomy of 'matter' and 'mind' (or 'spirit'). Plekhanov, Lenin, and other self-proclaimed 'orthodox' Marxists relied on the authority of Engels and argued that all philosophical positions can be divided into examples of 'materialism' and examples of 'idealism' depending on whether they take 'matter' or 'mind' to be the primary substance. Although originally framed as a problem of cognition (epistemology), the debates among Russian Marxists quickly escalated to the general ontological level. If the world is 'out there' and cannot be directly accessed and acted upon, then the overall view of reality that thus presents itself is rather discouraging; instead of being actively engaged in changing the world through revolution, human beings find themselves locked 'inside' their minds, unable not only to influence external reality but even to clearly discern its main constitutive elements.

Steila's essay tackles the difficult task of making sense of the philosophical differences among various factions by suggesting a helpful change of pace, if not perspective. Instead of trying to map the differences on the traditional distinction between Lenin's 'theory of reflection' and Bogdanov's so-called Machism (a derogatory designation that, like many of Lenin's apt nicknames, stuck around and became an acceptable descriptor), the author proposes a simple but effective comparison: Lenin's concept of perception is akin to photography, while Bogdanov's version is more like cinema. Yes, the metaphors themselves come from these respective authors, but their aptness is what is at stake in the essay in question. Lenin's subject is a passive recipient of the object's attributes that are reflected, as if in a mirror, in the subject's sense-apparatus. The subject takes a photograph of the object and, thus, having faithfully reproduced all of its aspects, 'knows' it. A static camera ('mind') fixes a static representation of the external reality ('matter'). Bogdanov's theory of cognition eliminates the distinction between the subject and the object, between the 'inside' and the 'outside' (here following Richard Avenarius's famous critique of 'interjection'), thus creating a world of moving perceptions akin to the work of a cinematographer. Instead of a static point (an 'individual'), we get a moving point (a 'social subject') filming moving reality and producing an infinite series of perceptions that can only provisionally be labelled 'objects' or 'things'. References to the work of Sergei Eisenstein open previously unexplored avenues for further elaboration of these insights into a fully-fledged new epistemology of subject-less (impersonal) cinematographic perception. 


\section{References}

Biggart, J. 2021. Bogdanov's Sociology of the Arts. Cultural Science Journal, 13.

Blackmore, JT. 1972. Ernst Mach, Berkeley: University of California Press.

Bogdanov, AA. 1923. Princip otnositel'nosti s organizatsionnoi tochki zreniia. Teoriia otnositel'nosti Einshteina i ee filosofskoe istolkovanie. Moscow: Mir, 101-122.

Bogdanov, AA.1924. Obektivnoe ponimanie principa otnositel'nosti (Metodologicheskie tezisy). Vestnik Kommunisticheskoi Akademii, 8: 332-347.

Bogdanov, AA. 1984. Red Star. The First Bolshevik Utopia. Edited by Loren R.Graham and Richard Stites, translated by Charles Rougle. Bloomington, Indianapolis: Indiana University Press.

Bogdanov, AA.1989. Tektologiia. Vseobshchaia organizacionnaia nauka. 1. Moscow: Ekonomika.

Bogdanov, AA. 1995. Neizvestnyi Bogdanov. Kniga 3. Edited by N.S. Antonova and N.V. Drozdova. Moscow: AIRO - XX.

Bogdanov, AA. 1996. Bogdanov's Tektology, Book 1. Edited and translated by Peter Dudley, Vadim N. Sadovsky and Vladimir V. Kelle. University of Hull: Centre for Systems Studies.

Bogdanov, AA. 2016. The Philosophy of Living Experience. Popular Outlines. Trans. and ed. by D. G. Rowley. Leiden; Boston: Brill.

Bogdanov, AA. 2019. Empiriomonism. Essays in Philosophy, Books 1-3, ed. and trans. by D. G. Rowley. Leiden - Boston: Brill.

Dauge, PG. 1907. K russkomu izdaniiu. Ernest Untermann, Antonio Labriola i losif Ditsgen, St. Petersburg: P.G. Dauge.

Dietzgen, J. 1870-1875. The Religion of Social-Democracy. Six Sermons. Joseph Dietzgen 1906. Some of the Philosophical Essays on Socialism and Science, Religion, Ethics, Critique-of-Reason and the World-at-large. Chicago: Kerr, 90-154.

Einstein, A. 1951. Autobiographisches / Autobiographical Note. Albert Einstein: Philosopher-Scientist, edited by Paul A. Schilpp. Stuttgart: W. Kohlhammer Verlag, 1-35.

Eisenstein, S. 1949. Film Form. Essays in Film Theory. Edited by J. Leyda. New York: Harcourt, Brace \& World.

Engels, F. 1886. Ludwig Feuerbach and the End of Classical German Philosophy. Karl Marx and Friedrich Engels, 1990. Collected Works 26, 353-398. London: Lawrence and Wishart.

lushkevich, PS. 1907. losif Ditsgen. Ocherk ego filosofii, Obrazovanie, 9: 69-89.

lushkevich, PS. 1923. Teoriia otnositel'nosti i ee znachenie dlia filosofii. Teoriia otnositel'nosti Einshteina i ee filosofskoe istolkovanie. Moscow: Mir, 123-155.

Kautsky, K. 1909. Über Marx und Mach. Der Kampf, 10: 451-452; O Markse i Makhe, Vozrozhdenie, 9-12: 77-80.

Lenin, VI. 1904. To His Mother. January 8, 1904. Vladimir Lenin. 1967. Collected Works 37, 359. Moscow: Progress Publishers.

Lenin, Vl. 1909. Materialism and Empirio-Criticism. Vladimir Lenin. 1962. Collected Works 14, 17-388. Moscow: Progress Publishers.

Lenin, VI. 1913a. A 'Scientific' System of Sweating. Vladimir Lenin. 1963. Collected Works 18, 594-595. Moscow: Progress Publishers.

Lenin, Vl. 1913b. Organisation of the Masses by the German Catholics. Vladimir Lenin. 1966. Collected Works 36, 244-246. Moscow: Progress Publishers.

Lenin, VI. 1920. Directions Concerning the Work of the Propaganda-Instructor Trains and Steamers. Vladimir Lenin. 1969. Collected Works 42, 160-161.

Lenin, VI. 1921. Once Again on the Trade Unions, the Current Situation and the Mistakes of Trotsky and Bukharin. Vladimir Lenin 1965. Collected Works 32, 70-197. Moscow: Progress Publishers. 
Lenin, VI. 1924. How the 'Spark' was Nearly Estinguished. Vladimir Lenin. 1960. Collected Works 4, 333-349. Moscow: Progress Publishers.

Lenin, VI. 1925. Directives on the Film Business. Vladimir Lenin 1969. Collected Works 42, 388-389. Moscow: Progress Publishers.

Lenin, VI. 1928. Theses on Production Propaganda. Vladimir Lenin. 1966. Collected Works 31, $404-$ 406. Moscow: Progress Publishers.

Lenin, VI. 1930. Draft Programme of the R.C.P.(B.). Vladimir Lenin. 1965. Collected Works 29, 97-140. Moscow: Progress Publishers.

Lenin, Vl. 1933. Ideological Decay and Disunity Among Russian Social-Democrats. In Vladimir Lenin 1963. Collected Works 16, 107-109. Moscow: Progress Publishers.

Mach, E. 1908. Analiz oshchushchenii i otnoshenie fizicheskogo k psikhicheskomu, 2-oe izd., Moskva: Skirmunt.

Marx, K. 1867. Marx to Ludwig Kugelmann. 7 December. Karl Mark and Frederick Engels 1987. Collected Works, 42, 496-497. London: Lawrence and Wishart.

Nevskii, V. 1920. Dialectical Materialism and the Philosophy of Dead Reaction. Vladimir Lenin. 1927. Materialism and Empirio-Criticism, 329-336. New York: International Publishers.

Plekhanov, GV. 1892. Predislovie k pervomu izdaniiu ('Ot perevodchika') i primechaniia Plekhanova k knige F. Engelsa: Liudvig Feierbakh i konets klassicheskoi nemetskoi filosofii. Georgii Plekhanov 1956. Izbrannye filosofskie proizvedeniia, 1. Moscow: Gospolitizdat.

Sechenov, IM. 1892. Predmetnaia mysl' i deistvitel'nost'. Ivan Sechenov. 1952. Izbrannye proizvedeniia 1, 465-485. Moscow: izd.vo AN SSSR.

Steila, D. 1991. Genesis and Development of Plekhanov's Theory of Knowledge. A Marxist Between Anthropological Materialism and Physiology, Dordrecht: Kluwer.

Steila, D. 2009. From Experience to Organization: Bogdanov's Unpublished Letters to Bazarov. Vesa Oittinen, Editor, Aleksandr Bogdanov Revisited. Helsinki: Aleksanteri Series, 1: 151-172.

Steila, D. 2013. Nauka i revoljucija. Recepciia empiriokrititsizma v russkoi kul'ture (1877-1910 gg.). Moscow: Akademicheskii Proekt.

Tikka, P. 2009. Tracing Tectology in Sergei Eisenstein's Holistic Thinking. Oittinen, Vesa, Editor, Aleksandr Bogdanov Revisited. Helsinki: Aleksanteri Series, 1, 211-234.

Vainshtein I. 1925. Iskusstvo i organizatsionnaia teoriia. Vestnik Kommunisticheskoi Akademii, 11: 204-222.

Valentinov, N. 1908. Filosofskie postroeniia marksizma. Moscow: Sotrudnik provincii.

Wark, M. 2015. Molecular Red: Theory for the Anthropocene. London-New York: Verso (ebook).

\section{Authors information}

Daniela Steila is Professor of History of Russian Philosophy at the University of Turin (Italy). She studied in Turin, Saint Petersburg, and Paris, and received her PhD from the University of Florence in 1991. She has written on Russian Marxists (Plekhanov, Bogdanov, Gor'kij, Lunacharskij), Russian reception of empiriocriticism, Russian philosophical historiography, the philosophical implications of L. S. Vygotskij's thought, Merab Mamardashvili, and Aleksandr Zinov'ev. Her research interests include the interactions between Russian and European philosophies since the nineteenth century, the quest for'Russian identity', and the history of Russian and Soviet thought. Among her books are Genesis and Development of Plekhanov's Theory of Knowledge (Kluwer, 1991) and Scienza e rivoluzione (Le Lettere, 1996), translated into Russian (Nauka i revoljucija, Akademicheskij Proekt, 2013). 
Evgeni V. Pavlov (PhD, University of Denver) teaches philosophy at the Metropolitan State University of Denver. He is the co-editor, with David G. Rowley, of Bogdanov Library (bogdanovlibrary.org), a Brill series that aims to translate the main works of Alexander Bogdanov. He is also the editor and translator of Evald Ilyenkov's collection of essays on Hegel and dialectics (Intelligent Materialism, Brill, 2019) as well as the translator of Valery Podoroga's Mimesis: Essays on Analytic Anthropology of Literature (Verso, 2022). 